\title{
Hammerstein: uma história alemã
}

Eloá Heise ${ }^{1}$

EnZensberger, Hans Magnus. Hammerstein ou a Obstinação. Trad. Samuel Titan Jr. São Paulo, Companhia das Letras, $2009^{2}$

Foi lançada em junho no Brasil, pela Companhia das Letras, com a presença do autor, a biografia ficcionalizada da família von Hammerstein, sob o título Hammerstein ou a Obstinação, de Hans Magnus Enzensberger. O texto original em alemão, Hammerstein oder Der Eigensinn - eine Deutsche Geschichte, de janeiro de 2008, foi traduzido para o português por Samuel Titan Jr., livro que recebeu fomento do programa de apoio à tradução pelo Goethe-Institut.

Esta obra, de difícil classificação, apresenta-se como uma colagem histórica sobre a vida do aristocrata Hammerstein e sua família. Kurt von Hammerstein tornou-se General de Infantaria e comandante do exército, o cargo mais alto do Exército Alemão, na época em que o nacional-socialismo ascende ao poder. Em fevereiro de 1933, depois de um jantar no qual esteve presente "um certo Hitler", o anfitrião começa a sentir o cargo como um fardo pesado demais, o que o leva a pedir a própria exoneração, renúncia aceita em fevereiro de 1934. Esse oficial de alta patente parece perceber, antes de seus pares, a catástrofe que se anunciava e, em oposição ao fluxo dos acontecimentos, não se deixa ofuscar em uma época na qual Hitler contava com o apoio das grandes massas. Se a história de Hitler é bastante conhecida, menos conhecida é a biografia de alguém, como Hammerstein, que, com senso próprio, teve o discernimento de permanecer fiel a si mesmo e de resistir à argumentação de um ditador psicopata.

Ao criar um quebra-cabeça histórico, com a inserção e inúmeras datas e citações entre aspas, o que leva o leitor a interpretá-las como manifestações diretas, colhidas de fontes consultadas, acrescidas de "conversas póstumas", diálogos de cunho ficcional

\footnotetext{
${ }^{1}$ Professora doutora de Pós-graduação no Programa de Língua e Literatura Alemã da Faculdade de Filosofia, Letras e Ciências Humanas da USP; eloaheise@usp.br

${ }^{2}$ Os números entre parênteses após as citações correspondem aos números das páginas da edição supracitada.
} 
com personagens tratados no livro, Enzensberger, em uma combinação livre, joga com a objetividade de um historiador e a licença poética de um escritor. A coleta desses dados só foi possível após a queda do muro e a partir de 1989, época em que as fontes russas se tornaram acessíveis, período do governo Gorbachev. As pesquisas historiográficas do autor, que se estenderam por três anos, contaram com o auxílio de Reinhard Müller, conhecedor da história do comunismo alemão. Algumas informações, por exemplo, foram garimpadas nos arquivos de Moscou, onde se encontra o discurso em que Hitler mostra seus planos de guerra aos generais, em um jantar na casa de Hammerstein, estopim para a manifestação de coragem civil deste general prussiano em relação ao nacional-socialismo. Outros detalhes sobre as fontes, arquivos consultados, pessoas que colaboraram com a pesquisa, mapa das ilustrações, índice onomástico, encontram-se arrolados no fim do livro, caracterizando o texto como uma pesquisa de base científica. Contudo esse aspecto de cientificidade é dissipado pela falta de referências na inserção das citações e com a mescla de trechos de cunho literário.

O motivo pelo qual Enzensberger interessou-se pela saga dessa família é mencionado em uma dessas “conversas póstumas”, que entremeiam a narrativa. Nela, um interlocutor designado pela inicial E, afirma: “A história de sua família me interessa porque ela diz muito sobre como teria sido possível fazer frente a Hitler sem capitular diante dele.” (171)

Paralelamente, o foco de interesse do autor volta-se para fatos poucos claros e conhecidos, apresentados pela perspectiva de várias fontes possíveis, muitas vezes em discrepante contradição. Da combinação do histórico com o ficcional obtém-se como resultado um rico quadro multifacetado sobre a história de uma época, de grandes nomes da política alemã e de uma figura peculiar, Kurt von Hammerstein, e sua respectiva família.

No transcorrer da narrativa, o foco de interesse se desloca para a vivência dos filhos do general, que assumem orientações diversas da postura do pai e vivenciam, por um viés próprio, os conturbados últimos anos da República de Weimar: engajam-se no movimento comunista, na Resistência alemã e, até mesmo na espionagem soviética. $O$ pai, nada convencional para o perfil de um general prussiano, no entanto, declara a quem quisesse ouvir: "Meus filhos são republicanos livres. Podem dizer e fazer o que bem entenderem” (65). 
Enzensberger não se propôs a escrever um romance, como ele mesmo afirma no post scriptum do livro, e muito menos um documento histórico. O autor mistura, no transcorrer do livro, citações colhidas em fontes autênticas, incursões biográficas, conversas imaginárias com personagens históricas, nas quais são vinculadas informações subjacentes e comentários subjetivos do narrador sob forma de sete glosas, que se mostram o instrumento ideal para comentar diferentes temas, seja sobre a República de Weimar, a aristocracia ou sobre as relações entre a Alemanha e a Rússia. Forma-se, assim, um painel a partir de 82 pequenas partes, que poderíamos chamar de capítulos, sem uma concatenação linear, em uma linguagem preponderantemente lacônica, com uma perspectiva distanciada, no qual se delineia uma história de época:

Com base na história da família Hammerstein, é possível, num espaço reduzido, reencontrar e apresentar todos os motivos e contradições decisivos do gravíssimo caso alemão: desde a tomada do poder total por Hitler até a embriaguez alemã entre Leste e Oeste, desde o colapso da República de Weimar até o fracasso da Resistência, e desde o fascínio pela utopia comunista até o fim de Guerra Fria. (317).

Tem-se, portanto, um texto de cunho artístico, literário, a partir de material autêntico, documental. A escolha do material autêntico, o princípio segundo o qual os recortes da realidade são montados, redunda em um enfoque direcionado, que se propõe, através da reconstrução obtida, uma possibilidade instigante de interpretação da história, ou seja, propicia reflexão baseada em um viés auxiliar da História.

A capa da edição brasileira omite, contudo, o subtítulo do original alemão “uma história alemã” - que estabelece essa relação clara com a história. No livro em português, o subtítulo só aparece na contracapa. A versão do Brasil, que visa atrair atenção para o conhecido nome de Hans Magnus Enzensberger, traz na capa, de forma paralela e com caracteres iguais, mas com destaques diferentes a partir das cores, o nome do autor e o título Hammerstein ou Obstinação. Talvez a palavra obstinação em português por também significar teimosia, irredutibilidade, pertinácia conota a atitude do protagonista com um elemento dinâmico que não corresponde à caracterização da personagem na narrativa.

Hammerstein não apresenta esse caráter de luta que a palavra obstinação dá a entender. É descrito, por diferentes fontes, de formas, muitas vezes, contraditórias: “E mesmo ele não tinha nada do alemão típico, trabalhador e consciencioso. Gostava de 
convívio, muitas vezes deixava o trabalho de lado e saía para caçar” (25). Ou, em contraposição: "Hammerstein era de confiança, era sóbrio, muito inteligente e sobretudo uma alma leal” (36). Em outras passagens coexistem na mesma página julgamentos que o censuram e o elogiam: "A confiança nele derivava unicamente de sua capacidade superior, de seu juízo claro e realista” (69), para mais adiante constatar: "comodismo exagerado e uma incrível falta de gosto pelo trabalho normal” (69). Esse protagonista, ao mesmo tempo inteligente e negligente, não poderia ser percebido como obstinado. Eigensinn deveria ser antes entendido como a qualidade de alguém com senso próprio, com uma capacidade de reconhecimento baseada em um subjetivismo que não se deixa encaixar. Essa individualidade faz com que não aja segundo as circunstâncias dominantes, e é isso que o transforma em um opositor de Hitler. Para ele vale a citação que lhe é atribuída (125) e aparece como mote do livro: “O medo não é uma visão de mundo” (5). Eis um protagonista típico do escritor e ensaísta Hans Magnus Enzensberger. : "Não sou nenhum herói. Você me toma por quem não sou. Quando chega a hora eu sustento a minha posição. Mas não vou sair empurrando a roda da história como vocês!” ... “Sou preguiçoso demais para isso!” (174).

Se o livro segue a biografia dos descendentes de Kurt Von Hammerstein, eles também são caracterizados pela reserva, sem laivos de heroicidade: "Mais importante era que em seu clã não houvesse um único nacional-socialista. Não são muitas as famílias que podem afirmar isso de si mesmas.” (247). As versões de suas histórias estão plenas de contradições, pois são resgatadas pela memória, e a memória também engana porque cada um recorda à sua maneira: "Perdura um resíduo não dito que nenhuma biografia pode resolver; e o que importa talvez seja justamente esse resíduo” (306). 